\title{
光弾性実験とFEM シミュレーションによるフェイズドアレイ計測音場の可視化
}

Visualization of sound field of phased array using photoelasticity system and FEM

\author{
○学 鹳森翔（富山大） \\ 正 三原毅（富山大） \\ 正 田代発造（富山大）
}

\section{Sho Washimori, Tsuyoshi Mihara, Hatsuzo Tashiro \\ University of Toyama, Gofuku 3190, Toyama}

Key Words: Ultrasonic wave, Phased array, Photoelasticity, Finite Element Method

\section{1. はじめに}

フェイズドアレイは、特に超音波挆甥において、音場を自 由に制御することで、広範围の計测結果堂迅速に画像化出来 る技術であり、近年の発電機器の経年損倁評洒の対策として、

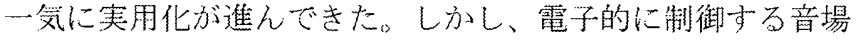
が設計通りに実現されているかの検証や、日的と正る計測対

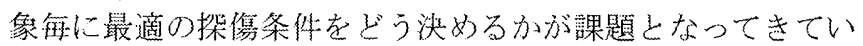
る。本報答では、著者らが開発、确究してきた光弾性超音波 伝搬可視化装置と、超音波伝搬に特化した大規模 FEM 在用い て、フェイズドアレイの入力音場を解析、検証した。

\section{2. フェイズドアレイ測定}

フェイズドアレイと经超波探傷法、才なわら超音波を用 いて構造物の内部の鹪を計測する方法の一種で夜る。

超音波は压電萻子に電压を印加し、振動させることで発生 する。通常の超音波探傷では监一の素子を用いているが (Fig.1)、フェイズドアレイでは細かく分割した複数の素子を 用いる。そして、それぞれの萎子から発生した波の波面を揃 えること心、伝搬波を構成方る（Fig.2(a)）。

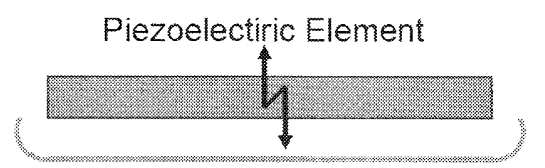

Uitrasonic Wave

Fig.l Normal Transducer

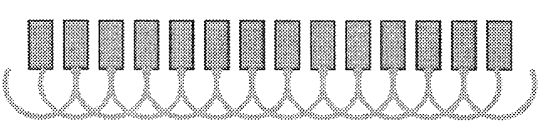

(a) Linear

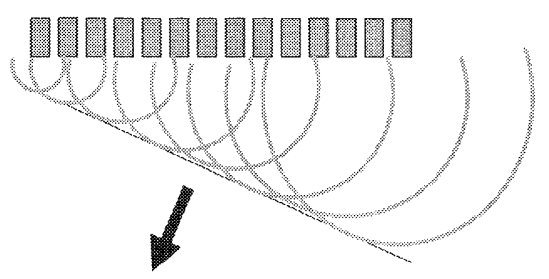

(b) Steering

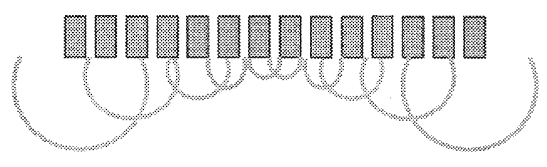

(c) Focusing

Fig.2 Phased Array Transducers
このように、フェイズドアレイでは複数の美子を用いるこ とが特徴であり、素子党同時に駆動させれば垂直方向に (Fig.2(a))、片側から順次駆動させてい怢代、意の角度に

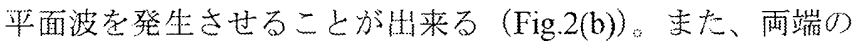
素子から中央へ順に駆動していくと、超音波学集束させるこ とが可能である(Fig.2(c))。

\section{3. 光弾性超音波伝搬可視化装置による可視化}

光弹性法とは灾力解析法の一種で市り、材料に心应力加え ると複屈折を起こす現象学利用したものである。

超音波以弹性波であるため、光弹性法を用いるこ上で、超 音波任搬の稼子坴可視化することが出莱る(1)。光弹性超音波 伝搬可視化装置の構成をFig. 3 に示古。

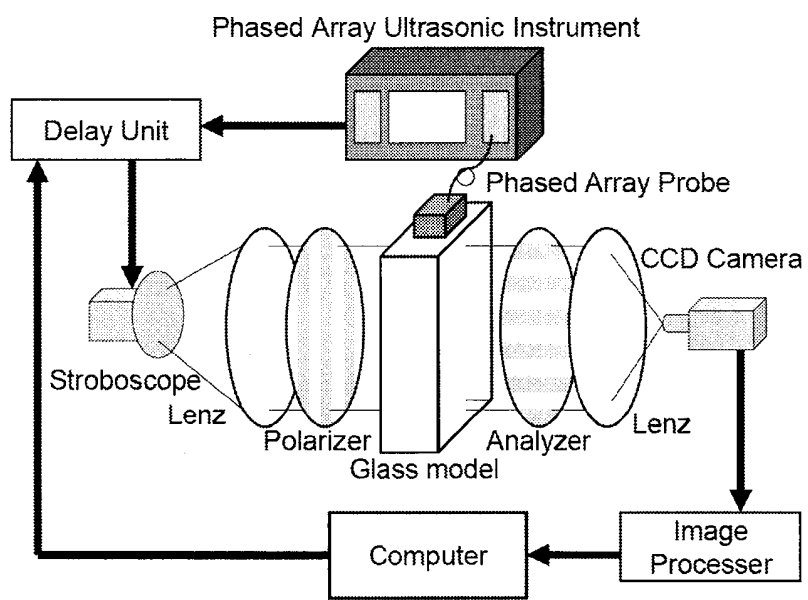

Fig.3 Ultrasonic visualization system using photoelastic method

フェイズドアレイの光弾性法による可視化は、フェイズド アレイ挆傷器方ら外部下リガーを光弾性可視化装置に同期さ せることで可能となっだ。

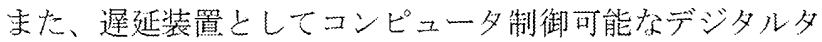
イミング・ジェネレー夕を尊入したことで、与える遅延時間

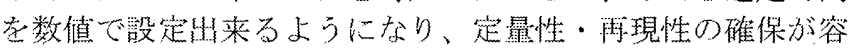
易になった。

フェイズドアレイでは Fig.2(b)に示した通り、任意の觕度 （ステアリング角）を設定できる。しかし、ステアリング解 が大きくなるにつれて、実際に波加谁行する角度とスデリ ング角とのずれが大きくなると報䇢されており ${ }^{(3)}$ 、乙の音場

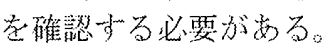

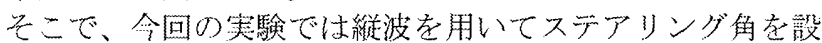
定し、ステアリング角を変化さ壮た場合について可視化を行 ot。

ここでは掫影した可視化画像から代表例として、Fig.4にス テアリング筩 $70^{\circ}$ で、ス卜ロボの荤延時間を $33 、 38 、 46 \mu \mathrm{s}$ の3 種を重衫て示す。 


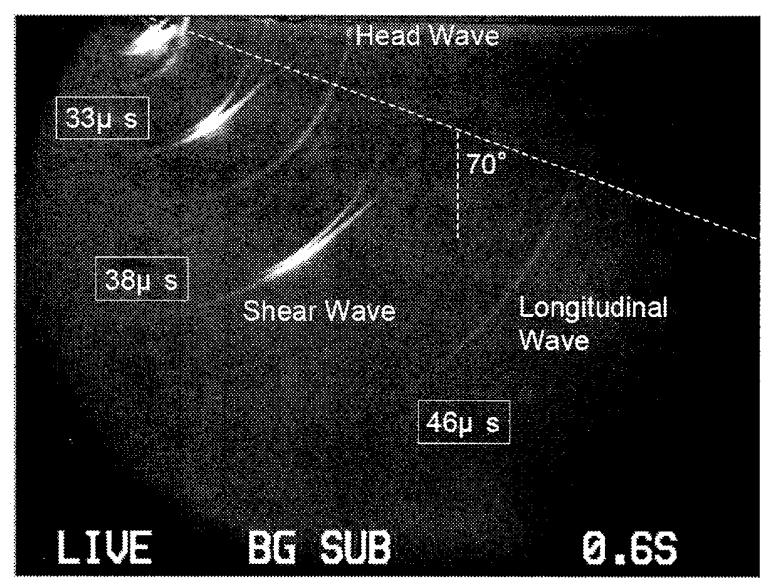

Fig.4 Photoelastic visualization image

\section{4. 大規模 FEMによる可視化}

FEM（Finite Element Method：有限要絭法）上は、領域在有 限の要素に分制・離散化ずることで数值計算老行う乎法であ り、超晢波の伝搬シミュレーションにおいては最も正確な解 析を行うことができる。

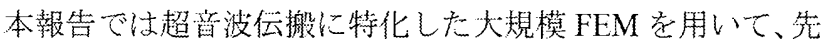
述の光弹性可視化害験での条件に扣い下解析・可視化を行っ to

フェイズドアレイ振動子の設定条体を Table1 に、試駼片の 設定条件老 Table2 に示す ${ }^{(4)}$ 。また、素子老駆動寸る時開（遲 延時閵）の設定は、Azar bの論文に上る ${ }^{(5)}$ 。

Fig.5 にこれらの条件で大規模 FEM による解析在行って得

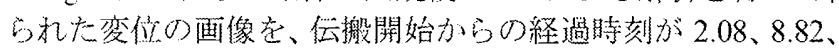
$16.35 \mu \mathrm{s} の 3$ 種を重教て示す。

Tablel Phased array parameters

\begin{tabular}{l|c}
\hline \hline Element material & PZT \\
\hline Element width & $0.4[\mathrm{~mm}]$ \\
\hline Element pitch & $0.5[\mathrm{~mm}]$ \\
\hline Number of Element & 16 \\
\hline Frequency & $4[\mathrm{MHz}]$ \\
\hline
\end{tabular}

Table2 Test block properties

\begin{tabular}{l|c}
\hline \hline Test block material & Quarts glass \\
\hline Longitudinal wave velocity & $5570[\mathrm{~m} / \mathrm{s}]$ \\
\hline Shear wave velocity & $3510[\mathrm{~m} / \mathrm{s}]$ \\
\hline Density & $2.7 \times 10^{3}\left[\mathrm{~kg} / \mathrm{m}^{3}\right]$ \\
\hline
\end{tabular}

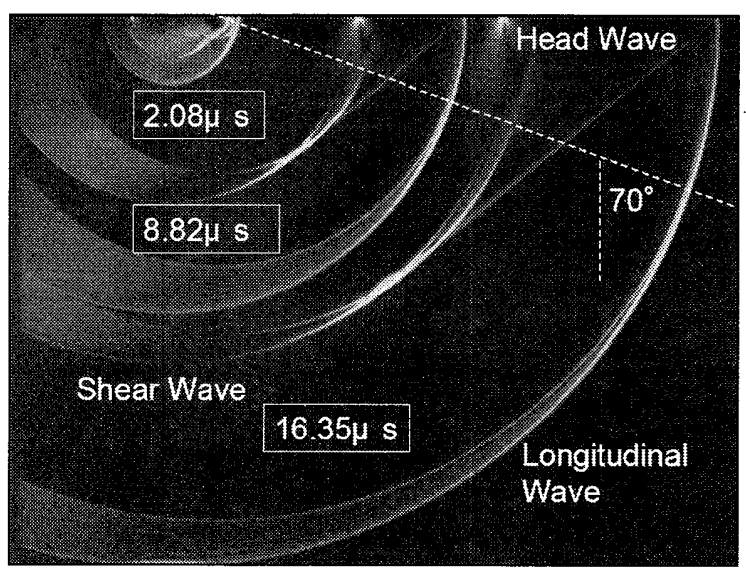

Fig.5 FEM visualization image

\section{5. 考察}

本節では、3 節と 4 節で可視化した結果学比較し、フエイ ズドアレイの残場について检証する。

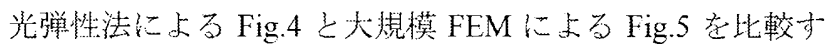

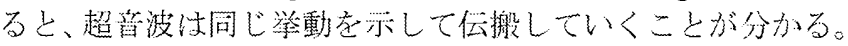
こ机性、大規模 FEMの妥当性も更している。

次に、フェイズドアレイの籍場について検証技る。Fig.4 孛

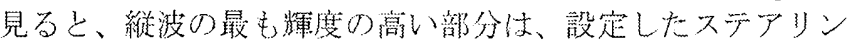
グ角 $70^{\circ}$ 上りも小さな角度に進行して行くこ上が分かる。 これは Fig.5でも同様である。

この原因としては、素子から発生和石超新波の指向性によ

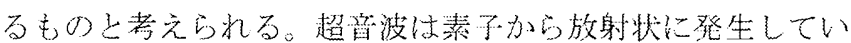
万坊、大靦模 FEM で見る限り、鉛直方向の伝搬强度が最も強 く、水平少向にいくにつ陗て強度は弱くなっていく。

そして、70 などの水平方向に近い大きなステアリング角

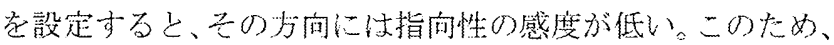

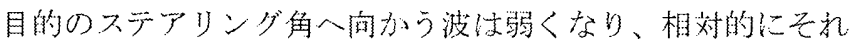

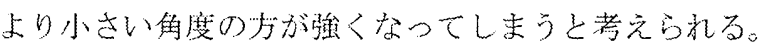

その他に、Fig.4ではHead Wave が発生している。光弹性法 では、 $0^{\circ}$ から $45^{\circ}$ 辺りまでは Head Wave が確諗出来ず、46 以隆で俆々に輝度代上がって確認出来るようになる。

これに対して大規模 FEMでは $0^{\circ}$ から既に Head Wave が発 生している。このことから、光弹性法でも $0^{\circ}$ から Head Wave は発生しているものの、輝度少小さいた如確認出来ないも

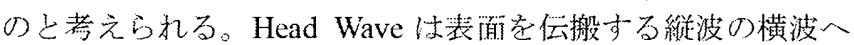
のモード変換波であり、スデアリング角が表目に近いほど、 その强度怄大きくなると考えられる。

\section{6. 結論}

本報告ではフェイズドアレイに上る超紫波伝搬色光弹性法

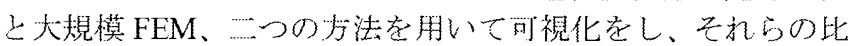
較、検証在行った。

光弾性法は䒠用アレイによる篹験が可能なので、実際の現 象を植接観察でさる。しかし、ダイナミックレンジには限界 があり、輝度が弱い部分は確認しづらい。

これに対して大規模 FEM はあくまでシミュレーションで あるため、設定条件に上る不整合も考えられる。しかし、解 析結果は数值デ一タによって定量的に表されるため、結果の 検証は容易である。

以上より、光弹性法と大䙺模FEM は互いに短所在補完しあ えるため、フェイズドアレイの音第解析には有用である。

7. 参考文献

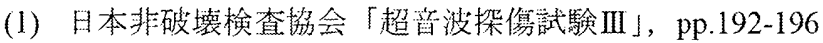

(2) 真川、古村：現行の規格に準拠したきす検出へのPhased array UT の適用、日本非破壞検查協会平成 20 年麻秋 季大会清演概要集、pp.15-16

(3) 藤原、木本、䱋瀨：大射場の放射バターンを用いるリ ニアアレイ探触子の喑計变数決定法、悠用力学諭文 集,vol.6(2003)、pp.1089-1096

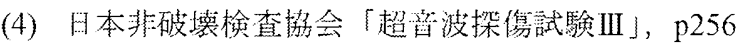

(5) L.Azar, Y.Shi、 S.-C.Wooh:Beam focusing behavior of linear phased arrays、NDT\&E International,vol 33(2000), pp.189-198 